\title{
Treatment management of giant retroperitoneal localized liposarcoma
}



1 Dicle University Faculty of Medicine, Department of General Surgery, Diyarbakır, Turkey.

Received: 10.06.2020; Revised: 01.09.2020; Accepted: 03.09.2020

\begin{abstract}
Liposarcoma is a tumor that reaches large diameters inside soft tissue tumors. It is rare. It is more common in people between the ages of 4060. Liposacoma patients are mostly asymptomatic, so their diagnosis may be delayed.

A 65-year-old female patient was admitted to our clinic. She had complaints of mass and pain in her abdomen. Abdominal examination revealed a mass extending to the pelvic area. The patient was evaluated by examination and radiology. Retroperitoneal liposarcoma diagnosed. Since the mass captured the left colon and kidney, the patient underwent left nephrectomy and left hemicolectomy. After histological and immunohistochemical examination, the patient was diagnosed with well-differentiated liposarcoma. The patient was evaluated with abdominal and pelvic computed tomography at the postoperative 4th month. No recurrence was observed in computed tomography scans. With the review of the literature, we found that the giant well-differentiated liposarcoma case extending into the pelvic region was scarce.

In this study, a rare case with giant well-differentiated liposarcoma that fills the abdomen almost completely is presented and the clinical features and surgical management of these tumors are discussed.
\end{abstract}

Keyword: Retroperitoneal Space, Surgical Procedure, Well Differentiated Liposarcoma, Case report

\section{Dev Retroperitoneal Liposarkomun Tedavi Yönetimi}

$\ddot{0} \mathbf{z}$

Liposarkom, yumuşak doku tümörlerinde büyük çaplara ulaşan bir tümördür. Nadirdir. 40-60 yaşları arasındaki kişilerde daha yaygındır. Liposarkom hastaları çoğunlukla asemptomatiktir, bu nedenle tanıları gecikebilir.

65 yaşında bayan hasta kliniğimize başvurdu. Karnında kitle ve ağrı şikayetleri vardı. Karın muayenesinde, pelvik bölgeye kadar uzanan kitle vardı. Hasta muayene ve radyolojik olarak değerlendirildi. Retroperitoneal liposarkom tanısı kondu. Kitle sol kolon ve böreği ivvaze ettiği için hastaya sol nefrektomi ve sol hemikolektomi ameliyatı yapıldı. Histolojik ve immünohistokimyasal incelemeden sonra hastaya iyi diferansiye liposarkom teşhisi kondu. Hasta postoperatif 4. ayda karın ve pelvik bilgisayarlı tomografi ile değerlendirildi. Bilgisayarlı tomografi taramalarında nüks gözlenmedi. Literatürün gözden geçirilmesiyle pelvik bölgeye uzanan dev iyi diferansiye liposarkom olgusunun az olduğunu bulduk.

Bu çalışmada, karnı neredeyse tamamen dolduran dev iyi diferansiye liposarkomlu nadir bir olgu sunulmuştur ve bu tümörlerin klinik özellikleri ve cerrahi yönetimi tartışılmıştır.

Anahtar kelimeler: Retroperitoneal alan, Cerrahi teknik, İyi differansiye liposarkom, olgu sunumu.

DOI: $\mathbf{1 0 . 5 7 9 8 / \text { dicletip.800317 }}$

Correspondence / Yazışma Adresi: Hüseyin Bilge, Dicle University Faculty of Medicine, Department of General Surgery, 21280, Diyarbakır, Turkey e-mail: dr.huseyinbilge@hotmail.com 


\section{INTRODUCTION}

Liposarcomas are rare soft tissue tumors. Soft tissue malignancies constitute $1 \%$ of all malignancies and liposarcomas constitute 9.8$16 \%$ of soft tissue malignancies ${ }^{1}$. Liposarcoma can affect adipose tissue, especially deep soft tissues, retroperitoneum, and extremities ${ }^{1,2}$. Retroperitoneal liposarcoma (RLS) usually affects perirenal adipose tissue. RLS is the most common sarcoma of retroperitoneal soft tissue, but it affects only $0.1 \%$ of all retroperitoneal malignancies $^{3}$. Liposarcoma can occur at any age, but it usually occurs in patients between the ages of 40 and 60 , and the average age is 53 . Some studies reported that men are dominant.

Patients with RLS have no specific findings, so the diagnosis of RLS is delayed ${ }^{4}$. Progress is different for each case. The progression of the tumor in patients may be different. Liposarcomas are slowly progressing tumors and can be stable for months or even years. Especially, asymptomatic retroperitoneal liposarcomas may grow to a large size ${ }^{5}$. Gastrointestinal, genitourinary, and hepatobiliary symptoms are seen rarely. Signs and symptoms including constipation, hydronephrosis, hernia, abdominal pain and varicose veins in the lower extremities are associated with tumor size. Despite other advanced tumor patients, patients with liposarcoma do not have nutritional deficiency and weight loss.

According to the World Health Organization (WHO), liposarcomas are divided clinically, pathologically, and genetically into 3 subgroups: myxoid/round cell liposarcomas, well-differentiated liposarcomas, and pleomorphic liposarcomas. Due to the increasing knowledge about histological, immunohistochemical, and genetic features of liposarcomas, these subgroups are better known 6 .

RLS treatment is surgery. The contribution of chemotherapy or radiotherapy is controversial.

Despite other liposarcoma patients, the prognosis of patients with RLS is worse ${ }^{7}$.

In this study, we reported a patient with RLS who was taken to surgery and discussed current approaches for the diagnosis and treatment of RLS.

\section{CASE PRESENTATION}

\section{Chief complaints}

A 65-year-old women presented to the General Surgery Department of our hospital complaining of abdominal mass.

\section{History of present illness}

Patient's symptoms started six month ago. No previous disease history.

\section{History of past illness}

The patient had a free previous medical history. Physical examination

In clinical abdominal examination; the mass was palpated from the left hypochondrium to the pelvic region. There was no abdominal pain.

\section{Laboratory examinations}

Laboratory findings were not specific and tumor markers were normal. The blood biochemistries, as well as urine analysis were normal. Electrocardiogram, chest X-ray and arterial blood gas were also normal.

\section{Imaging examinations}

Abdominal and pelvic computed tomographic (CT) scan showed a heterogeneous mass from the perirenal region on the left side to the pelvic region. The tumor size was $24 \times 32$ centimeters (cm) in which was multiple solid components. 
Abdominal structures were pushed to the right side and the pelvic region was full of the mass. There was rotation anomaly in the left kidney due to mass (Figure 1).

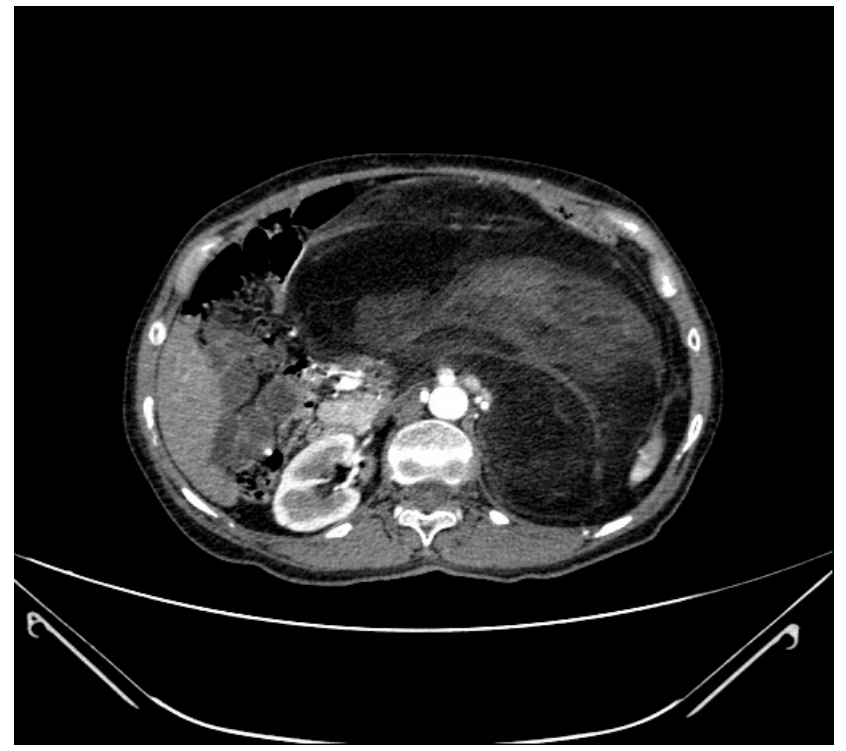

Figure 1. Preoperativly axial computed tomography image

Due to the imaging findings mentioned above, preliminary diagnosis was made as retroperitoneal liposarcoma.

\section{Treatment}

The patient was hospitalized in the general surgery clinic. Considering abdominal CT findings, surgical operation was planned with the preliminary diagnosis of RLS. All quadrants of the abdomen were full of the mass which originated from the left perirenal fatty tissue adjacent to the kidney, ureter, left colon (Figure 2). The patient received complete resection of the liposarcoma, left nephrectomy and left hemicolectomy (Figure 3). The tumor had invaded the left colon and kidney. Left colectomy and nephrectomy were performed for un block tumor resection. The size of the mass was $40 \times 25 \times 15 \mathrm{~cm}$ (Figure 4). She was discharged asymptomatic after 1 week of hospitalization.

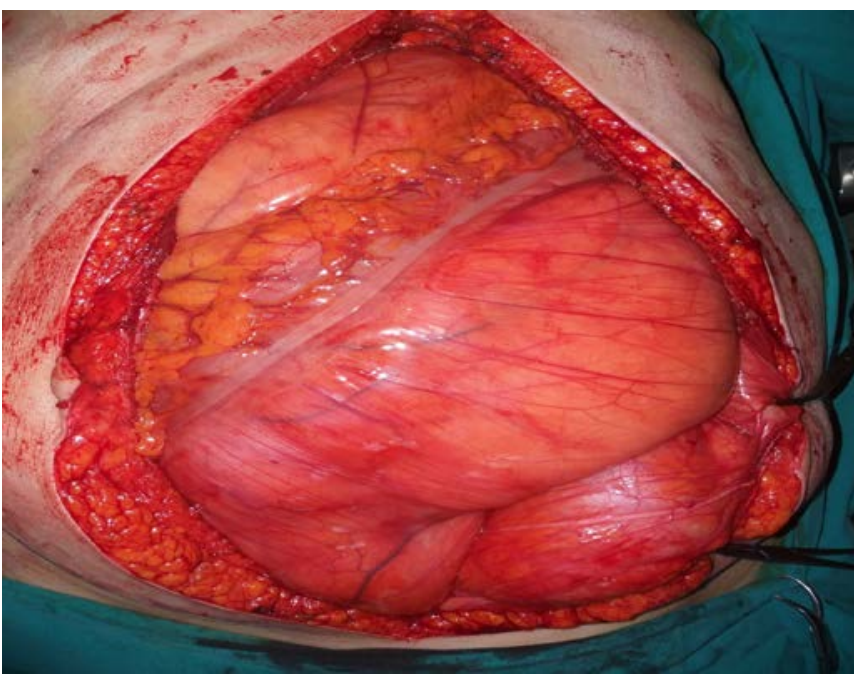

Figure 2. Intraoperativly appearance of the mass

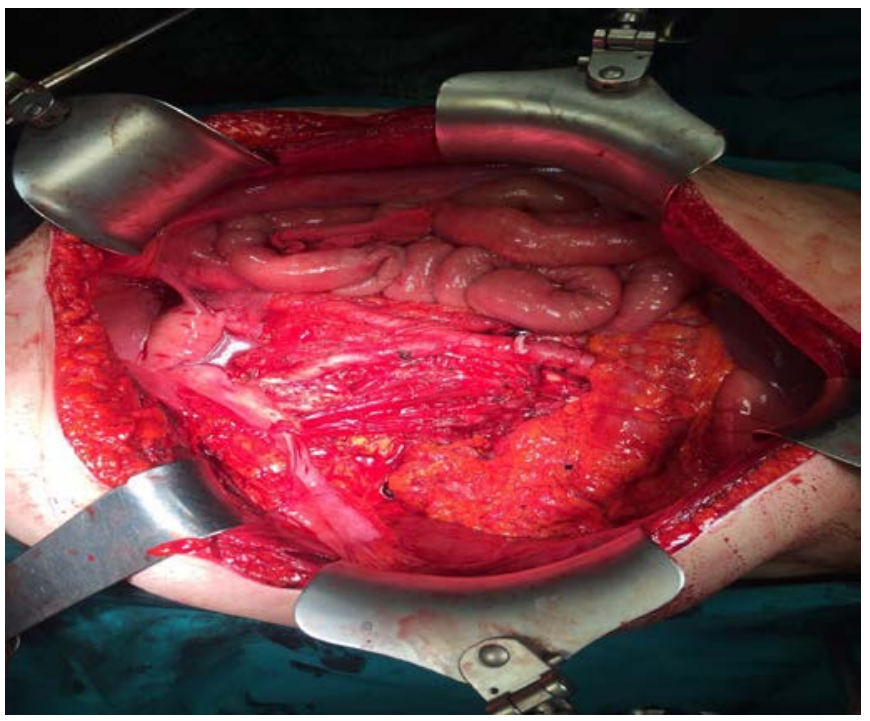

Figure 3. The abdomen after resection

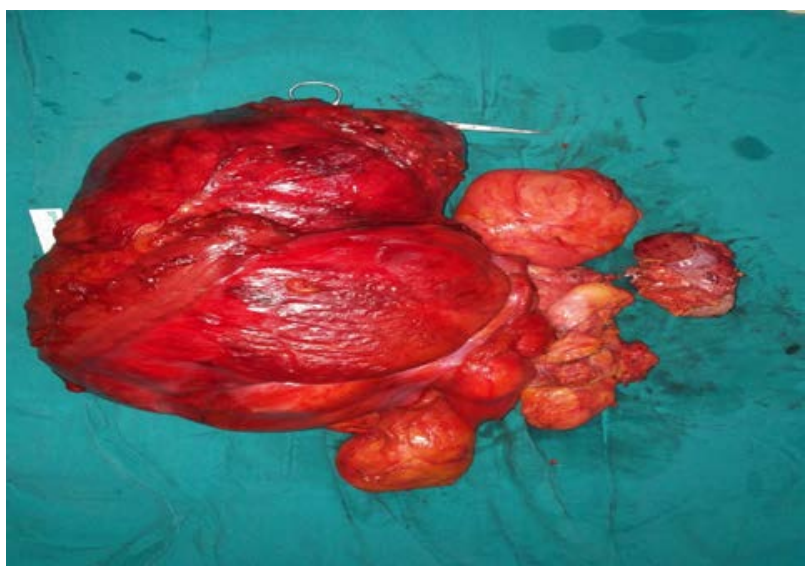

Figure 4. The patological material 


\section{Outcome and Follow-up}

In the pathological examination of the mass, its size was $41 \times 26 \times 15 \mathrm{~cm}$ and it had a full fibrous capsule and multilobular structure. According to the WHO classification, histopathological diagnosis was grade 1 well-differentiated liposarcoma.

Abdominal and pelvic CT was obtained at the 4 th postoperative month. No recurrence and residual findings were seen on CT scans (Figure $5)$.

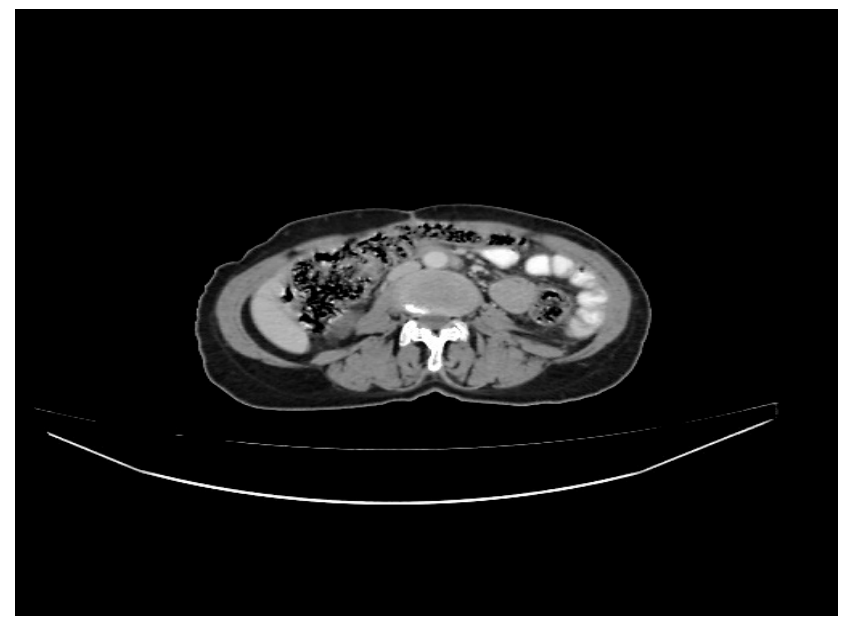

Figure 5. Postoperativly 4th month, axial computed tomography image

\section{DISCUSSION}

Primary liposarcomas are soft tissue tumors that expand locally without invasion of surrounding tissues. It can also grow in a different place like a tumor different from the primary tumor. Often liposarcomas are surrounded by a false capsule-like other soft tissue sarcomas. This capsule is formed with flat and weak tumor cells ${ }^{7}$. The case we present is rare in the literatüre. In our case, we revealed a patient who grew up to include the left kidney.

The first imaging test is an abdominal ultrasound, but all patients should have CT or magnetic resonance (MR) imaging. We diagnosed RLS using abdominopelvic CT. The diagnosis and treatment of RLS is multidisciplinary. Surgeons, pathologists, radiologists, radiation oncologists, and medical oncologists should be in this group 8 . Our patient was evaluated preoperatively by radiology and diagnosed with CT, and the surgical technique was decided along with urology during the operation.

With only pathological examination, liposarcoma is diagnosed. If the tumor is resectable, surgery is ideal for treatment. Resection of large-sized tumors is not always possible. Performing surgical biopsy may be appropriate, before definitive surgery is performed. Retroperitoneal neoplasms are more likely to be liposarcomas compared to benign lipomas. Therefore, total excision without biopsy may be the best treatment by considering the possibility of liposarcoma 5 . For this reason, we applied surgery to our patients who were not biopsied.

Stout et al. divided liposarcomas into 4 classes according to histopathological and clinical behaviors; Type I: Well-differentiated myxoid type, Type II: Undifferentiated myxoid type, Type III: Round cell or adenoid type, Type IV: Mix type. In many studies, there are wide histological appearance differences in different parts of the same tumor. Many author agree that it is difficult to estimate the histological background of all biological behavior. Recurrent liposarcomas tend to be more aggressive and anaplastic than primary tumors ${ }^{3}$. Welldifferentiated liposarcomas are low-grade tumors that do not metastasize as in our case.

The metastasis of liposarcoma can be at any part of the body, however, lungs, liver, and lymph nodes are the common areas of metastasis. In despite of local control of the primary tumor, it can be the metastasis of distant organs. There was no early metastasis in our patient.

Generally, aggressive radical excision due to anatomical location, size, and local spread is considered as liposarcoma treatment. Blocked resection should be done to the patient with 
sarcoma, as is universally accepted ${ }^{9,10}$. Due to the easy disintegration of the pseudocapsule, enucleation of the tumor often causes multiple local recurrences. Even if the tumor remains stable, invasion of the vital organs can cause mortality on the patient with recurrence. We applied unblock-resection on our patient and sent it for the pathological examination (Figure 4). The most dangerous complication of retroperitoneal resection is injuries of mesenteric vessels, aorta, inferior vena cava, renal artery, and renal vein. The mortality rate of RLS resection is $12-36 \%{ }^{5,9}$.

Generally, radiation therapy is used for the treatment of residual liposarcoma, local recurrences, inoperable tumors, and metastatic tumors ${ }^{11}$. Preoperative radiotherapy can technically make primary inoperative liposarcomas resectable. Even if the tumor is not destroyed, the radiotherapy may provide good palliation and prolong survival. The radiotherapy is effective for microscopic, residual, and small-size tumors. However, it is ineffective for recurrent, inoperable, and nonresectable tumors as a permanent ablation treatment. If it is technically possible, the tumor must be resected.

Reitan et al. analyzed the prognostic effect of various diagnostic and treatment modalities on 99 patients with liposarcoma. This study showed that tumor size, histologic subtype, and X-ray density were the important prognostic factors and also that the liposarcomas were affected by the using treatment modalities. Liposarcomas do not respond to any conventional systemic chemotherapy which has been already reported ${ }^{12}$.

The local recurrence ratio of RLS is $20-85 \%$ after surgical resection ${ }^{5}$. Distant metastasis develops in more than half of the patient who shows local recurrence ${ }^{13}$.

It is suggested that aggressive resection, radiotherapy, or combined therapy are used for the treatment of recurrent diseases. Although most of recurrences repeat clinically in 2-5 years after the treatment, they can also occur much later. That's why the long-term follow up is important $\mathrm{t}^{3,5}$.

\section{CONCLUSION}

Consequently, the patients apply to the hospital late, due to RLS expands to large-size without any symptom. These patients have unclear as clinically. The diagnosis and treatment of liposarcoma should be evaluated as multidisciplinary. Radical surgical resection should be preferred in the treatment. The late recurrences should be kept in mind and the long-term follow up should not be ignored.

Informed consent statement: Informed written consent was obtained from the patient for publication of this report and any accompanying images.

Declaration of Conflicting Interests: The authors declare that they have no conflict of interest.

Financial Disclosure: No financial support was received.

\section{REFERENCES}

1. McGuinness LA, Floyd Jr MS, Lucky M, et al. Myxoid liposarcoma of the scrotum in a 27-year-old male successfully treated with primary excision and testis preservation. Journal of Clinical Urology. 2015; 8: 285-6.

https://journals.sagepub.com/doi/abs/10.1177/2 051415813514970

2. Chrisinger JS, Al-Zaid T, Keung EZ, et al. The degree of sclerosis is associated with prognosis in welldifferentiated liposarcoma of the retroperitoneum. Journal of Surgical Oncology. 2019; 120: 382-8. https://onlinelibrary.wiley.com/doi/full/10.1002/j so. 25585

3. Baum SH, Mohr C. Metastases from distant primary tumours on the head and neck: clinical manifestation and diagnostics of 91 cases. Oral and Maxillofacial Surgery. 2018; 22; 119-28. 
https://link.springer.com/article/10.1007/s10006 -018-0677-y

4. Seelig $M H$, Winkels $R$, Wiese $M$, Weyhe $D$. Spermatic cord liposarcomas incidentally found during hernia surgery: is histology of any lipoma mandatory? A review of the literature. Acta Chirurgica Belgica. 2020; 120: 79-84.

https://www.tandfonline.com/doi/full/10.1080/0 0015458.2019.1689645

5. Spieler P, Rössle M. Kidney, Adrenal Glands, Retroperitoneum In Nongynecologic Cytopathology. Berlin, Heidelberg: Springer, 2012: 731-95.

6. Yorke J, Agbenorku P, Awoonor-Williams R, et al. Management of Retroperitoneal Liposarcoma: A Case Report. Surgical Science. 2016; 7: 361. https://www.scirp.org/html/6-

2301046_69985.htm

7. Sari SY, Cengiz M, Dauletkazin A, et al. Hypofractionated radiotherapy for non-metastatic bone and soft tissue sarcomas. Cancer/Radiothérapie. 2019; 23: 853-9. https://www.sciencedirect.com/science/article/pii /S1278321819303932

8. Van Houdt WJ, Raut CP, Bonvalot S, et al. New research strategies in retroperitoneal sarcoma. The case of Tarpswg, Strass and Resar: making progress through collaboration. Curr Opin Oncol. 2019; 31: 310-6. https://journals.lww.com/cooncology/fulltext/2019/07000/new_research_stra tegies_in_retroperitoneal.12.aspx

9. Rasulov RI, Dvornichenko VV, Muratov AA, Songolov GI, Mozgunov DV. İnorganik retroperitoneal tümörler: geçmiş ve şimdiki. Sibirya Tıp Dergisi (Irkutsk). 2015; 138. https://mir.ismu.baikal.ru/src/downloads/e4957c 16_4_smzh_7_2015(s5-56).pdf

10. Neoplasien AP. 9.Neoplasien des Unterhautbindegewebes (primäre und metastatische). Rheumatologie C: Spezieller Teil II Wirbelsäule, Weichteile, Kollagenerkrankungen, $2013 ; 330$.

https://books.google.com.tr/books?hl=tr\&lr=\&id= nAmgBgAAQBAJ\&oi=fnd \&pg=PA330\&dq=Neoplasi en+A.+P.+9.+Neoplasien+des+Unterhautbindegewe bes+(prim\%C3\%A4re+und+metastatische).+ Rheu matologie+C:+Spezieller+Teil+II+Wirbels $\%$ C3\%A4 ule,+Weichteile,+Kollagenerkrankungen,+2013\%3 B330.\&ots=dSLuXGnNw7\&sig=SsC7VrpG2Ykj6ScF VTPepABy0gM\&redir_esc $=y \# v=$ onepage $\& q \& \mathrm{f}=$ false

11. Brenneman R. J., Sharifai N., Fischer-Valuck B., et al. (2019). Abscopal effect following proton beam radiotherapy in a patient with inoperable metastatic retroperitoneal sarcoma. Frontiers in Oncology, 9, 922.

https://www.frontiersin.org/articles/10.3389/fon c.2019.00922/full

12. Lee HS, Yu JI, Do Hoon Lim SJK. Retroperitoneal liposarcoma: the role of adjuvant radiation therapy and the prognostic factors. Radiation oncology journal. 2016; 34: 216. https://www.ncbi.nlm.nih.gov/pmc/articles/PMC5 066451/

13. Akpak YK, Gün İ, Kaya N, Atay V. A rare case of leiomyoma: Retroperitoneal leiomyoma. Dicle Tip Dergisi. 2014; 41: 414-17. https://dergipark.org.tr/tr/download/articlefile/53872 